\title{
Long-term variability in bivalve recruitment, mortality, and growth and their contribution to fluctuations in food stocks of shellfish-eating birds
}

\author{
J. J. Beukema*, R. Dekker, C. J. M. Philippart \\ NIOZ Royal Netherlands Institute for Sea Research, PO Box 59, 1790AB Den Burg, Texel, The Netherlands
}

\begin{abstract}
Bivalve biomass in coastal marine areas tends to fluctuate heavily from year to year, but the relative impact of underlying processes (such as recruitment, mortality, and growth) on this variability is poorly known. The present study deals with 3 bivalve species that live on tidal flats and are readily exploitable as food for shellfish-eating birds, which have suffered in recent years from short food supply in the Wadden Sea. Long-term ( $40 \mathrm{yr})$ monitoring of bivalve populations on tidal flats in the western Wadden Sea has revealed high year-to-year variability in numerical densities, whereas variability in growth rates and resulting mean individual weights-at-age was relatively low. High biomass values were found in particular when strong cohorts had arisen from successful recruitment in preceding years, whereas failing recruitment for some years in succession led to low biomass of bivalve stocks. Occasionally, temporarily enhanced mortality rates resulted in temporarily strongly reduced biomass values. Only in Macoma balthica were biomass values (at similar foregoing recruitment and mortality levels) lower in years with below-average individual weights than after years with above-average ones. In all 3 species, processes that govern numbers rather than individual weights were most decisive for biomass variability. Recruitment and mortality rates in only 3 species together explained a significant proportion of the variability of the total (multi-species) bird-accessible bivalve biomass. The low bird-food supply in recent years in the Wadden Sea appears to be due to a shift in the major structuring factors since the mid-1990s: as a consequence of the absence of cold winters in the area after 1997, annual recruitment in some major bivalve species has consistently failed and was not sufficiently compensated by better survival. A recent period of consistently enhanced mortality rates in $M$. balthica even aggravated the situation.
\end{abstract}

KEY WORDS: Recruit density $\cdot$ Survival rate $\cdot$ Individual weight $\cdot$ Cerastoderma edule $\cdot$ Mytilus edulis $\cdot$ Macoma balthica $\cdot$ Shortage of bird food $\cdot$ Tidal flats $\cdot$ Wadden Sea

Resale or republication not permitted without written consent of the publisher

\section{INTRODUCTION}

Bivalves are a major constituent of the zoobenthic biomass in coastal waters. For instance, on the tidal flats of the western Wadden Sea, they accounted for no less than 60 to $70 \%$ of the total macrozoobenthic biomass in both the 1970s and the 1980s (Beukema 1976, 1991) as well as in more recent decades (Dekker 2009). Similar proportions were reported by Dörjes et al. (1986) for the eastern Wadden Sea. In the tidal-flat ecosystem, bivalves play essential roles both as consumers of phytoplankton and as a food source for shell- fish-eating birds. According to calculations by Swennen (1976), Smit (1983) and Scheiffarth \& Nehls (1997), no less than $\sim 70 \%$ of the food consumption (by weight) of birds in the Wadden Sea consists of molluscs (almost exclusively bivalves).

In temperate coastal areas, bivalve biomass values are notoriously variable through time (e.g. on Wadden Sea tidal flats: Beukema et al. 1983, 1993, Dörjes et al. 1986, Essink et al. 1998). Species-specific biomass may range from close-to-zero values in some years to several tens of grams ash-free dry mass in other years, as observed in e.g. Cerastoderma edule (Möller 1986, 
Dörjes et al. 1986, Beukema \& Dekker 2006), Mytilus edulis (Obert \& Michaelis 1991, Beukema \& Dekker 2007), Macoma balthica (Beukema et al. 2009) and Mya arenaria (Möller 1986). The occurrence of low bivalve stocks is not without consequences for population dynamics at higher trophic levels. The Wadden Sea is an important foraging area for huge numbers of birds. Several authors (Camphuysen et al. 1996, 2002, Ens et al. 2006, Kats 2007, Piersma 2007, Kraan et al. 2009) have reported temporary food shortage in the Wadden Sea for shellfish-eating birds (eiders Somateria mollissima, oystercatchers Haematopus ostralegus, and red knots Calidris canutus) and consequent decline of their numbers (Van Roomen et al. 2005).

For Wadden Sea bivalves, a preponderant influence of recruitment on subsequent biomass is expected from earlier studies on the effects of initial cohort strength variability on subsequent production: Cerastoderma edule (Beukema \& Dekker 2006), Macoma balthica (Van der Meer et al. 2001, Dekker \& Beukema 2007), and Mytilus edulis (Beukema \& Dekker 2007). Under specific circumstances, however, mortality was observed to contribute strongly to biomass variability, e.g. in cockles $C$. edule as a consequence of severe winters (Beukema 1985, Strasser et al. 2001) and in mussels $M$. edulis caused by intensive fishery (Beukema 1993b). Individual annual weight gain can also vary strongly from year to year, as observed in the Wadden Sea in M. balthica (Beukema \& Cadée 1991). The relative importance of each of these processes for the between-year variability in total bivalve biomass appears to be largely unknown.

Long-term data series are available from almost $40 \mathrm{yr}$ of consistent macrozoobenthos monitoring, including twice-annual assessments of numbers and weights of bivalve populations at 15 sampling sites on Balgzand, a large tidal-flat area in the westernmost part of the Wadden Sea (Beukema et al. 2002). These data allowed estimates for several species not only of biomass, but also of annual rates of recruitment, mortality, and growth. The present study will be largely limited to the 3 main bivalve species that comprise by far most of the potential food of the shellfish-eating birds on Wadden Sea tidal flats (see Table 1): the cockle Cerastoderma edule (L.), the Baltic tellin Macoma balthica (L.), and the blue mussel Mytilus edulis L.

In the present paper, we explore the contributions to variability of total bivalve stocks (expressed as biomass $B$, in $\mathrm{g} \mathrm{m}^{-2}$ ) as the outcome of some underlying processes, viz. species-specific preceding rates of annual recruitment, mortality, and growth of the above 3 important species. By definition, a species' biomass $\left(\mathrm{g} \mathrm{m}^{-2}\right)$ at any time is the product of its numerical abundance $\left(\mathrm{n} \mathrm{m}^{-2}\right)$ and the mean weight of its individuals (g ind. ${ }^{-1}$ ). Therefore, biomass values can vary by changes in either numerical density or mean weight, or both. Between-year changes in numerical densities mainly result from magnitudes of preceding recruitment and mortality rates, changes in growth lead to changes in mean individual weights. Thus, each of the above processes may contribute to subsequent biomass variability. In the present study, we did not include possible contributions of migration to changes in numbers or biomass, because migration in Wadden Sea bivalves appears to be largely restricted to juvenile stages, occurring before the time of recruitment at age 0.8 yr (Beukema 1993a, Beukema et al. 1999).

Information on the relative importance of the above underlying processes on year-to-year changes in biomass of bivalves that are exploitable for birds might contribute to further understanding of possible causes (such as declining eutrophication, increasing temperatures, and disturbance by cockle/mussel fishery) of variability in carrying capacity for shellfish-eating birds in the Wadden Sea.

\section{MATERIALS AND METHODS}

Long-term field observations. Since around 1970, data on zoobenthos have been collected twice annually at 15 permanent sampling stations located on Balgzand, a $50 \mathrm{~km}^{2}$ tidal flat area in the westernmost part of the Wadden Sea. Further details on the sampling area, the stations, and the methods can be found in Beukema \& Cadée (1997). Numerical density and softparts biomass estimates of macrozoobenthic species (all animals in the bottom cores that were retained on $1 \mathrm{~mm}$ meshes) were expressed in $\mathrm{n} \mathrm{m}^{-2}$ and $\mathrm{g} \mathrm{m}^{-2}$, respectively. Weights were estimated as ash-free dry weights (ash-free dry mass, AFDM). Mean values of the 15 stations were used, sampled in late winter (mostly in March, at the time of annual minimum values of biomass). By allotting all individuals to age groups (usually from counts of annual shell marks), we obtained estimates of annual rates of recruitment and mortality and of individual weights-at-age. Annual recruitment was estimated as a 15-station average of densities $\left(\mathrm{n} \mathrm{m}^{-2}\right)$ of 0 -group animals in late winter (i.e. at an age of $\sim 0.8 \mathrm{yr}$ after settlement, but still of the small size attained after a few months of growth in their first summer). Annual mortality was estimated from changes in total late-winter densities (averages of $\mathrm{n} \mathrm{m}^{-2}$ at the 15 sampling stations) of animals that were at least $\sim 0.8 \mathrm{yr}$ old at the start of the year, and was expressed either as an instantaneous annual mortality rate $\left(z\right.$ in $\mathrm{yr}^{-1}$, calculated as the natural logarithm of the numbers of all individuals of all cohorts present in year $x$ in the samples divided by numbers of the same cohorts in year $x+1$ ) or as a percentage survival. 
Estimates of mean individual AFDM for individual cohorts were obtained by weighing dried soft parts of (groups of) individuals before and after ashing. Mean values for weights-at-age were assessed by dividing 15-sampling-station means of biomass of a cohort by mean cohort densities $\left(\mathrm{n} \mathrm{m}^{-2}\right)$. Whenever this quotient was based only on (a few) individuals originating from only 1 sampling station, we used a long-term mean to calculate estimates of expected biomass (see below). Standard errors were included as long as the number of cohorts present was at least 10 (n amounted to 40 for all age groups in Macoma balthica, but declined with age from $\sim 40$ at $0.8 \mathrm{yr}$ to close to 10 at 4.8 or $5.8 \mathrm{yr}$ in the other 2 species). In the case of Mytilus edulis, no data on weight-at-age were available for the 1970s (due to inadequate aging at that time).

In the present paper, we discuss only (size groups of) species that could play a significant role as bird food on Wadden Sea tidal flats. Therefore, we excluded hardly accessible size groups of some species (Zwarts et al. 1996), viz. large ( $>5 \mathrm{~cm}$ shell length) adults of Mya arenaria (which live deeply buried) and almost permanently immersed adults ( $>5 \mathrm{~cm}$ shell length) of Ensis directus. As birds frequently switch to other prey species whenever these are more profitable (3 or 4 species according to Zwarts et al. 1996), and different bird species take different types and size ranges of prey, we present biomass data not only for some individual species (Cerastoderma edule, Macoma balthica, Mytilus edulis), but also for totals of easily accessible bivalves.

Temperature data were taken from Van Aken (2008). Winters were (arbitrarily) classified as severe when the Jan-Feb-Mar mean water temperature was $<2^{\circ} \mathrm{C}$. This was so in 6 out of the 39 winters included in the present study (1970 to 2008, inclusive): 1970, 1979, 1985, 1986, 1987, and 1996.

Disturbance by fishery was of a limited nature on Balgzand. Details can be found in Beukema \& Dekker (2005): fishery for mussels occurred at 1 location for about 1 mo, for cockles at 1 location in a few years, and for lugworms in 2 areas for prolonged periods (Beukema 1995).

Calculations of expected biomass values. The annual estimates of weights-at-age and of rates of recruitment and mortality were used to evaluate the influence of these factors on subsequent (late-winter) biomass. To this end, we made estimates of expected biomass under the assumption that 2 (e.g. recruitment and mortality) of these 3 factors remained constant and variation in biomass was due to year-to-year variability during preceding years in the 1 other factor only (e.g. weight-at-age). We prefer this procedure over multiple regression analysis because the biomass of the studied bivalves at any time is usually made up of substantial contributions of several cohorts (Dekker \& Beukema
2007: their Fig. 4a) and strong cohorts can dominate biomass for several years (Beukema \& Dekker 2006: their Fig. 7), but the numbers of cohorts and years are variable. In the present calculation model, it was easy and straightforward to include contributions of cohorts born in several foregoing years, as long as these contributions were substantial. The summed estimates of cohort contributions were compared with observed biomass values of the species. For each species and condition, 30 to 35 expected values could be calculated, viz. for the years of around 1975 up to and including 2009 (for the earlier 1970s, expected values could not be calculated, because no data were available to estimate possible contributions of cohorts born before 1970 ).

To estimate the influence of net growth in preceding years on a species' biomass, we used mean individual weights ( $\mathrm{g}$ AFDM ind. ${ }^{-1}$ ) of the members of a cohort found at the time of the biomass observation and fixed numbers for the number of individuals of each cohort. These numbers were calculated from assumed constant recruitment (using the mean numbers of recruits shown in Table 1) and survival of these recruits in subsequent years. As a constant annual survival rate we took $60 \%$ for Macoma balthica (based on Van der Meer et al. 2001) and 33\% for the other 2 species (being roughly the long-term average we estimated).

To estimate the single effects of recruitment variability on subsequent biomass, we calculated per-recruit contributions to subsequent biomass to be expected at assumed fixed rates of annual survival (mentioned above) and growth. The products of estimates of long-term mean individual weights at various ages (solid points in Fig. 1) and proportions of recruits surviving to these ages (at the above assumed constant survival rates) are shown as open points in Fig. 1. For example, the expected contribution to biomass of an individual Cerastoderma edule recruit ( $0.8 \mathrm{yr}$ old) to biomass 2 yr later (at an age of $2.8 \mathrm{yr}$ ) would amount to $0.33^{2}$ times the mean recruit weight at an age of $2.8 \mathrm{yr}: 0.33 \times 0.33 \times 0.288=0.032 \mathrm{~g}$. The expected contribution to the biomass $\left(\mathrm{g} \mathrm{m}^{-2}\right)$ of the entire cohort at that age was then calculated by multiplying the above figure of $0.032 \mathrm{~g}$ by the recruit density ( $\mathrm{n}$ $\mathrm{m}^{-2}$ at an age of $0.8 \mathrm{yr}$ ). To calculate the (preceding-recruitment-based) expected total biomass in any year, the contributions to the biomass in that year of the then present individual cohorts were summed.

To estimate the single effects of mortality/survival on subsequent biomass, we used the long-term means of individual weights-at-age (solid points of Fig. 1) and fixed recruitment figures (Table 1). The latter were multiplied by the observed annual survival proportions to arrive at a figure for $\mathrm{n} \mathrm{m}^{-2}$ at each age and this figure was then multiplied by the value for mean weight-at-age to arrive at an expected biomass value. 


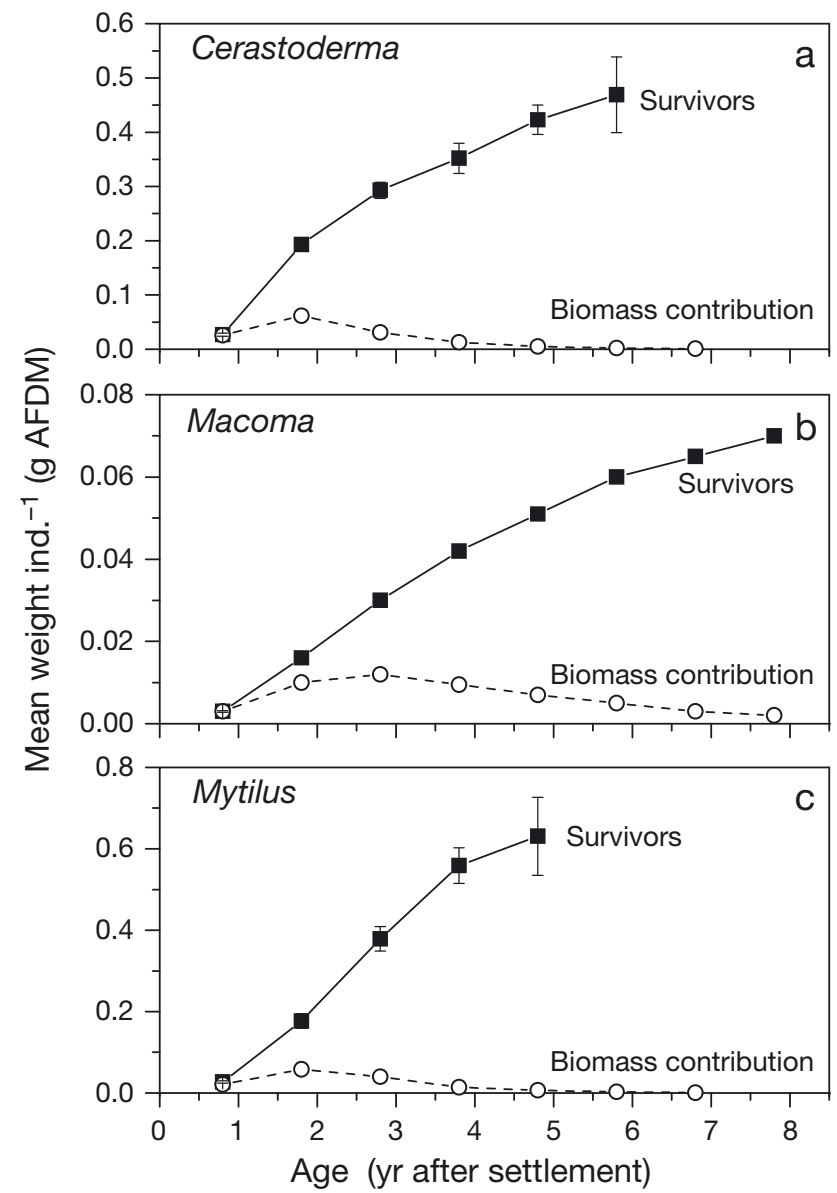

Fig. 1. (a) Cerastoderma edule, (b) Macoma balthica and (c) Mytilus edulis. Changes with age of mean individual latewinter weights of soft parts ( $\mathbf{\square}$, in $\mathrm{g}$ AFDM ind. $\left.{ }^{-1}\right)$ and calculated individual contributions per originally 0.8 -yr-old recruit to late-winter biomass at the given age $(O)$ $\left.\mathrm{m}^{-2}\right)$, and Mytilus edulis $\left(2.0 \mathrm{~g} \mathrm{~m}^{-2}\right)$. Small $(\leq 5 \mathrm{~cm}$ shell length) Mya arenaria (0.7 $\left.\mathrm{g} \mathrm{m}^{-2}\right)$ and a number of lowdensity species (together $0.4 \mathrm{~g} \mathrm{~m}^{-2}$ ) should be added to arrive at a total for accessible bivalve biomass.

Sums of biomass estimates of all species (or size groups of species) that are easily accessible as bird food amounted to a long-term average of nearly $10 \mathrm{~g}$ AFDM m ${ }^{-2}$ (Table 1) and were highly variable, ranging from $<5$ to $>20 \mathrm{~g} \mathrm{AFDM} \mathrm{m}^{-2}$. They more than doubled from low values around $5 \mathrm{~g}$ AFDM m ${ }^{-2}$ in the early 1970s to $10-20 \mathrm{~g} \mathrm{~m}^{-2}$ in most years between 1980 and 1995 (Fig. 2a). Thereafter, a steep decline occurred in the severe 1995/96 winter to a consistently lower level for the last decade. As cockles Cerastoderma edule contributed more than any other species, the total biomass values (Fig. 2a) are bound to show a pattern that is similar $\left(\mathrm{r}^{2}=0.74, \mathrm{p}<0.0001\right)$ to the one for cockles (Fig. 2b). Note that at the end of all 6 severe winters $(1970,1979,1985,1986,1987$, and 1996) and also $1 \mathrm{yr}$ later (samples taken in early 1971, 1980, 1988, and 1997) stocks were temporarily reduced (as compared to values found in neighboring years) both in cockles and in totals of all accessible bivalves (open points in Fig. $2 \mathrm{~b}$ and $\mathrm{a}$, respectively). These relatively low values were caused by extremely low over-winter survival at freezing temperatures in some species, especially in C. edule (Beukema 1985, 1990, Strasser et al. 2001). These high severe-winter mortality rates continued for some months after the severe winter and thus enhanced mortality rates in the subsequent year as well. A further reason why cockle biomass was still low $1 \mathrm{yr}$ after a severe winter is that cockles are then present almost exclusively as spat-sized individuals with rather low individual weights.
Full sets of late-winter data were available for all or nearly all of the 40 years of the 1969 to 2008 period. As we studied the influence of recruitment in a number of preceding years on subsequent biomass, we could include only biomass values of around 1975 and later years in the present analysis.

\section{RESULTS}

\section{Biomass of bivalves}

By far the bulk of the bird-accessible bivalve biomass ( $90 \%$; Table 1$)$ is comprised of the 3 species studied in detail: Cerastoderma edule (with a $40 \mathrm{yr}$ mean late-winter biomass of $4.3 \mathrm{~g}$ AFDM m $\left.\mathrm{m}^{-2}\right)$, Macoma balthica $(2.3 \mathrm{~g}$
Table 1. Cerastoderma edule, Macoma balthica and Mytilus edulis. Long-term ( 35 to $39 \mathrm{yr}$ ) averages and degree of variability of late-winter biomass (g AFDM $\left.\mathrm{m}^{-2}\right)$, recruitment success ( $\mathrm{n} \mathrm{m}^{-2}$ of spat-sized individuals in late winter), annual mortality (instantaneous rate of change in $\mathrm{n} \mathrm{m}^{-2}$ between successive late-winter samplings), and annual net growth (mean increase in weights of individuals between the ages of 0.8 and $1.8 \mathrm{yr}$, in $\mathrm{g}$ AFDM ind. ${ }^{-1}$ ) in Balgzand. Variability is expressed as coefficient of variation (c.v.)

\begin{tabular}{|c|c|c|c|c|c|c|c|c|}
\hline \multirow[t]{2}{*}{ Species } & \multicolumn{2}{|c|}{ Biomass } & \multicolumn{2}{|c|}{ Recruitment } & \multicolumn{2}{|c|}{ Mortality } & \multicolumn{2}{|c|}{ Growth } \\
\hline & Mean & C.v. & Mean & C.v. & Mean & C.v. & Mean & C.V. \\
\hline C. edule & 4.3 & 89 & 29 & 155 & 1.48 & 74 & 0.16 & 35 \\
\hline M. balthica & 2.3 & 58 & 50 & 70 & 0.67 & 48 & 0.013 & 27 \\
\hline M. edulis & 2.0 & 87 & 14 & 194 & 1.37 & 70 & 0.15 & 40 \\
\hline Sum $^{\mathrm{a}}$ & 8.6 & 55 & & & & & & \\
\hline Other bivalves & 1.1 & & & & & & & \\
\hline All acc. bivalves ${ }^{\mathrm{b}}$ & 9.7 & 50 & & & & & & \\
\hline \multicolumn{9}{|c|}{$\begin{array}{l}\text { a Total biomass of the } 3 \text { above species } \\
\text { bum of all bivalves accessible to birds (i.e. the } 3 \text { species plus biomass of } \\
\text { juvenile Mya arenaria and Ensis directus and total biomass of several low- } \\
\text { density species such as Scrobicularia plana, Tellina tenuis and Abra tenuis) }\end{array}$} \\
\hline
\end{tabular}



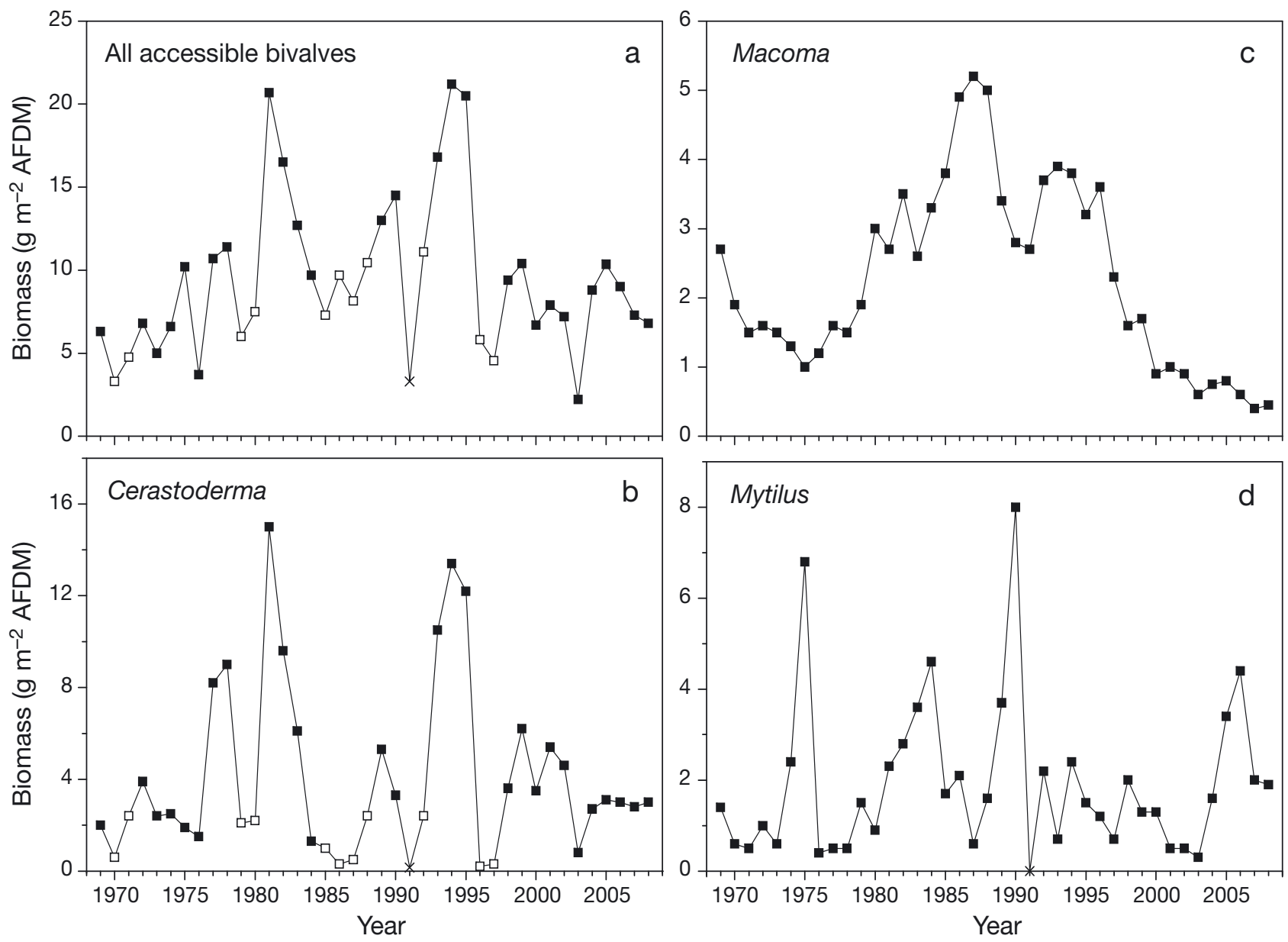

Fig. 2. Long-term data series of bivalve biomass (in $\mathrm{g} \mathrm{AFDM} \mathrm{m}^{-2}$ ) as observed in late winter in each year of the $40 \mathrm{yr}$ period of observation (1969 to 2008, inclusive) on Balgzand tidal flats (means of 15 sampling sites). (a) Sums of bivalve species that can be considered as easily accessible food for birds, thus excluding from the total bivalve biomass large specimens of Mya arenaria (>5 cm shell length) and Ensis directus (>5 cm shell length); (b) the cockle Cerastoderma edule only; (c) the Baltic tellinid Macoma balthica only; (d) the blue mussel Mytilus edulis only. $\mathrm{x}:(\mathrm{a}, \mathrm{b}, \mathrm{d} ; 1991)$ samples taken after a heavy fishery on the mussel and cockle stocks on Balgzand in the summer of 1990, reducing the adult stocks to close to nil. $\square$ : (a,b) samples taken either immediately after a severe winter (early 1970, 1979, 1985, 1986, 1987, and 1996), 1 yr later (1971, 1980, 1988, and 1997), or 1 yr after the intensive fishery (early 1992), when hardly any adult-sized cockles were present

Another strikingly low value for cockle (and total bivalve) biomass occurred in early 2003, after a colder than average but not really severe winter. Nevertheless, overwinter mortality in cockles was exceptionally high in early 2003, probably as a consequence of the unusual distribution of the cockles at that time: they were largely restricted to higher tidal flats (above mean tide level), where mortality is elevated in cold winters (Beukema 1985).

\section{Annual recruitment of bivalves}

In all 3 major species, recruitment showed strong between-year variability (Fig. 3a-c), with standard deviations far exceeding means in Cerastoderma edule and Mytilus edulis (Table 1). In Macoma balthica coef- ficients of variability were lower than in the other 2 species (Table 1) due to a lower frequency of close-tozero recruitment values.

As a consequence of the frequent occurrence of highly successful recruitment in summers following cold winters (Strasser et al. 2003), peaks in abundance of recruits of these 3 species tended to coincide (Beukema et al. 2001). Examples are the common peaks in the panels of Fig. 3 in early 1980 and 1988 of the cohorts born in 1979 and 1987, respectively, following the severe winters of these 2 years.

Note that highly successful recruitments did not occur in any of the 3 major species during the entire 13 yr period after 1995 (Fig. 3). Severe winters did not occur between 1997 and 2009 (see Fig. 1a in Beukema et al. 2009). 

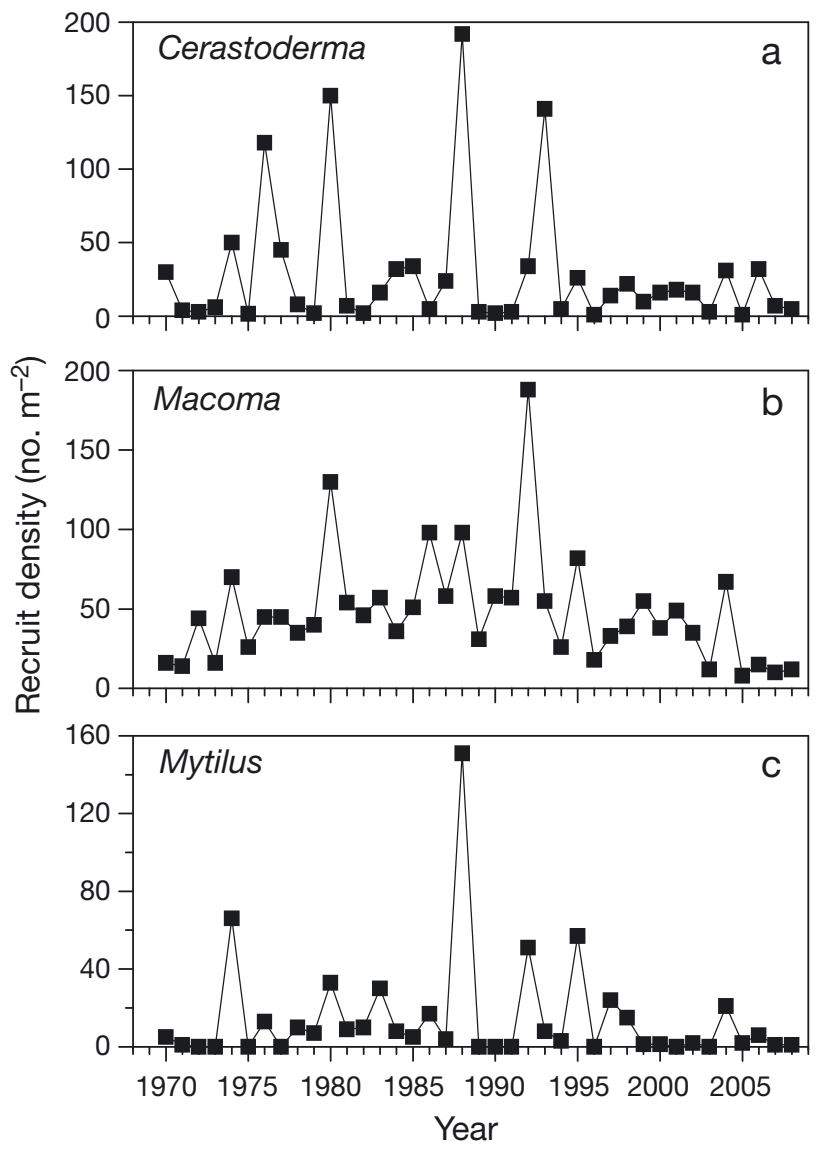

Fig. 3. (a) Cerastoderma edule, (b) Macoma balthica and (c) Mytilus edulis. Long-term (1969 to 2008) data series on the annual abundance $\left(\mathrm{n} \mathrm{m}^{-2}\right)$ of 0-group individuals observed in 40 late winters (between mid-February and mid-April) at Balgzand (averages of 15 fixed sampling stations)

\section{Annual mortality of bivalves}

Annual mortality rates varied from year to year, but did not show any obvious trends that were shared by the 3 species (Fig. $4 \mathrm{a}-\mathrm{C}$ ). Annual mortality and its variability were higher in Cerastoderma edule and Mytilus edulis than in Macoma balthica (Table 1). Note (Fig. 4b) that the mortality rates observed in the latter species were particularly low (on average, $z=0.51 \mathrm{yr}^{-1}$ ) and showed little variation (a coefficient of variation of only 23 ) for the initial $30 \mathrm{yr}$ period. The relatively constant mortality in this species (Van der Meer et al. 2001), however, increased at the end of the 1990s (though not exactly in the same year at all sampling stations) to stay at a roughly doubled level for most of the last decade (Fig. 4b). As a result, old individuals of this species became rare in the western Wadden Sea after 2000 (compare Fig. 7a of Dekker \& Beukema 2007) and this remained so even after lower mortality rates during the last few years.

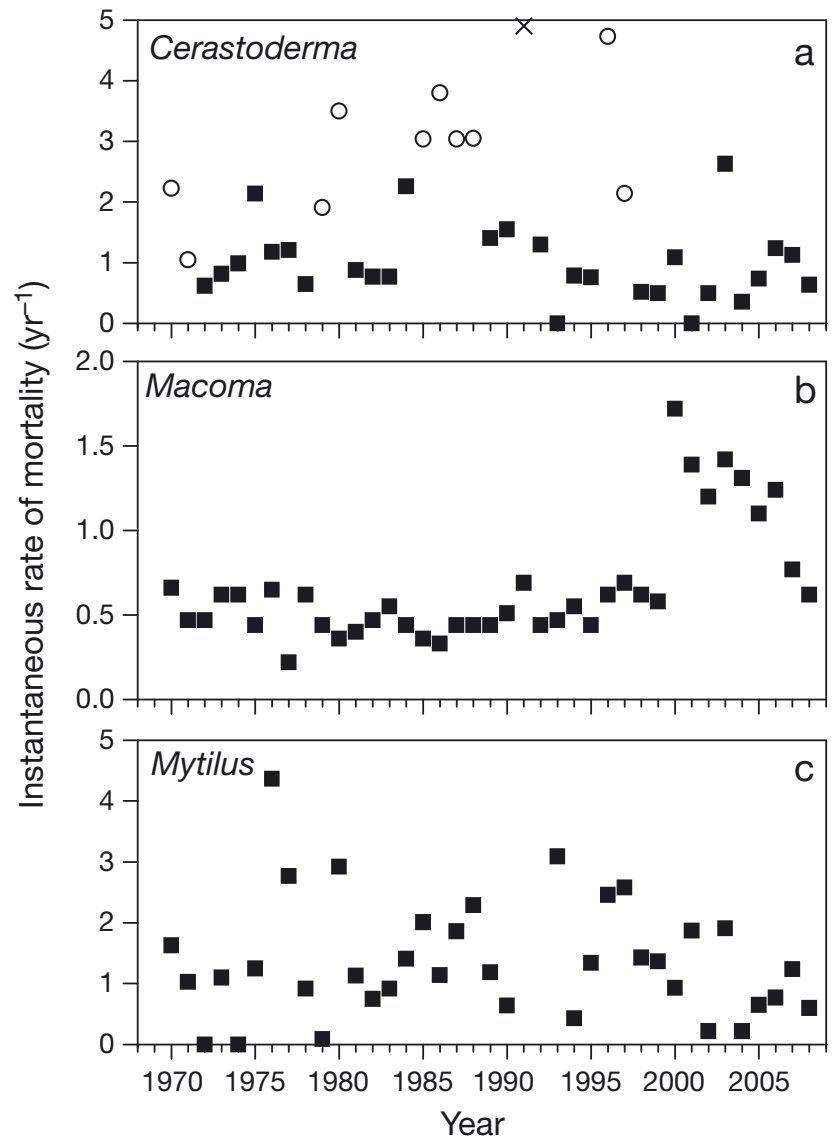

Fig. 4. (a) Cerastoderma edule, (b) Macoma balthica and (c) Mytilus edulis. Long-term series of estimates of annual mortality (expressed as an annual instantaneous rate $z$, in $\mathrm{yr}^{-1}$ ) based on numerical densities estimated in late winter of the years 1969 to 2008 at 15 sampling sites on Balgzand. X: (a) the extremely high mortality in 1990/91 due to fishery; a point for this year in (c) had to be omitted because no mussels were found in early 1991 at the sampling sites. O: (a) mortality rates affected by severe winters (see text: $z$ was elevated for 2 subsequent years)

For Cerastoderma edule, the open points in Fig. 4a refer to estimates that were influenced by severe winters, which seriously aggravate cockle death rates during the cold months and some subsequent months. Since elevated mortality rates by cold winters had not ended at the time of late-winter sampling, Fig. 4a shows not 1 but 2 open points for each severe winter. These winter-affected mortality rates were significantly higher than those for the other years (mean values of $z$ amounted to 2.8 and $1.0 \mathrm{yr}^{-1}$, respectively, $\mathrm{p}<0.0001$, Wilcoxon's rank sum test with $\mathrm{n}=10$ and 28 for severe winter-affected and other years, respectively).

In Mytilus edulis, annual mortality rates (Fig. 4c) were more variable than in Macoma balthica, but there was no specific pattern of enhanced mortality rates related to specific periods of severe winters. 


\section{Annual individual weights}

In all 3 bivalve species studied, year-to-year variation in individual weights-at-age varied less than either recruitment or mortality: maximal estimates were rarely $>5$ times higher than minimal ones (Fig. 5a-c). The underlying variation in year-to-year variation in annual growth was relatively low (as compared to annual rates of recruitment and mortality), as shown by relatively low coefficients of variation (Table 1).

There appear to be no obvious common patterns or long-term trends in the annual weights in the 3 species. In Cerastoderma edule and Macoma balthica (Fig. 5a,b), individual mean weights in the same year of 1.8 and $2.8 \mathrm{yr}$ olds were significantly correlated $\left(\mathrm{r}^{2}=\right.$ 0.26 and $0.48, \mathrm{n}=28$ and $40, \mathrm{p}<0.01$ and $\mathrm{p}<0.0001$, respectively), suggesting that favorable growing conditions for young animals were also favorable for individuals of higher ages.

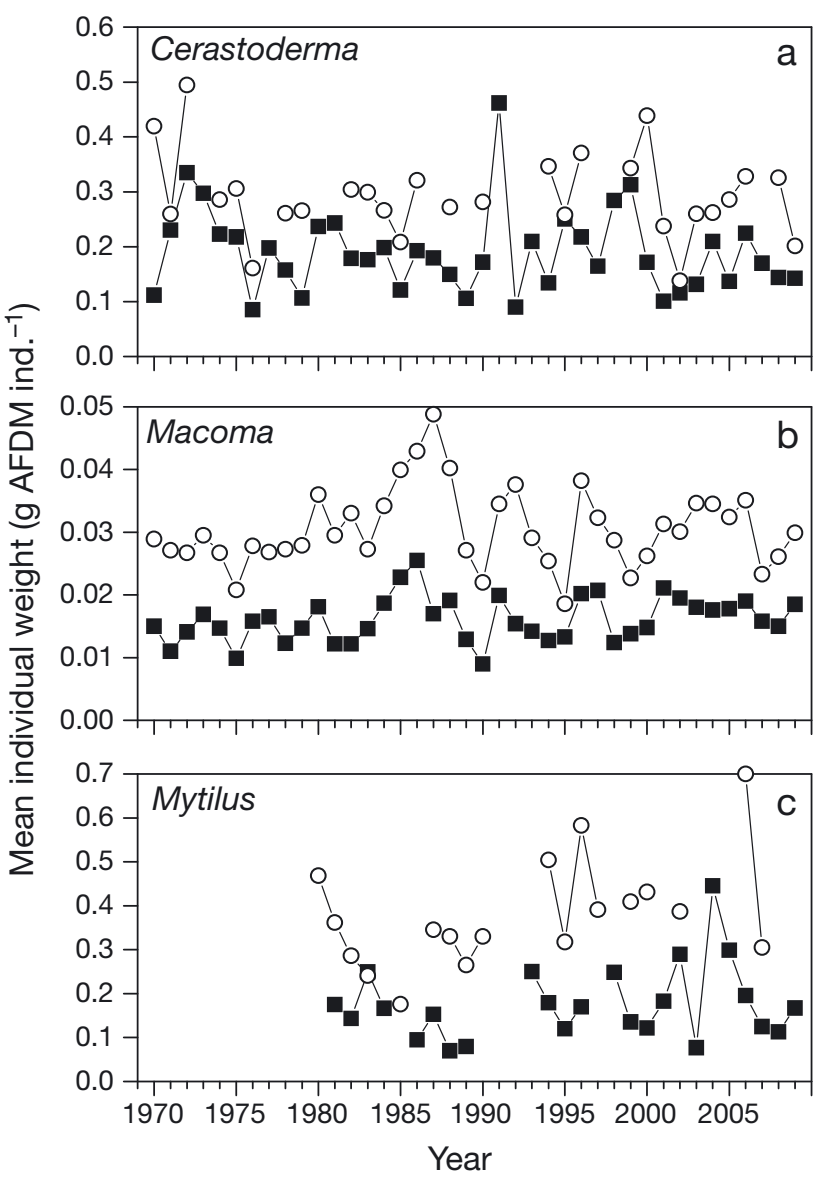

Fig. 5. (a) Cerastoderma edule, (b) Macoma balthica and (c) Mytilus edulis. Long-term series of estimates of annual mean individual weights ( $\mathrm{g}$ AFDM ind. ${ }^{-1}$ ) at an age of ( $\left.\boldsymbol{\square}\right) 1.8 \mathrm{yr}$ and (O) 2.8 yr. Data refer to the total Balgzand population of the species

\section{Influence of recruitment, mortality and individual weights on biomass}

In all 3 species, the calculated values of expected biomass that were based exclusively on variation in preceding recruitment (at constant mortality and growth) correlated well with observed biomass values (Fig. 6a-c). This was also the case for values based exclusively on variability in mortality rates (at constant recruitment and growth) as shown in Fig. 6d-f. Within species, the correlation coefficients hardly differed between relationships based on recruitment and those on mortality variability, suggesting that these 2 processes were of similar importance for future biomass. A comparison of the species reveals that the observed values were particularly close to the expected ones in Macoma balthica (Fig. 6b,e).

In contrast, relationships between observed and expected biomass values based exclusively on weight variation at supposedly constant recruitment and mortality were less close (Fig. 6g-i) and showed statistical significance in Macoma balthica only (Fig. 6h). In all species, expected biomass values that were based on variability in numbers (either recruitment: Fig. 6a-c, or mortality: Fig. 6d-f) showed closer relationships with (and were thus better predictors of) actual biomass than expected values based on variability in individual weights (Fig. $6 g-i)$. Note the relatively narrow ranges of the values of expected biomass that were based on variability in weights-at-age, in accordance with the relatively low between-year variability in growth (Table 1).

To give an impression of the relative magnitude of the effects on biomass of preceding rates of recruitment, mortality and growth, we present the data points shown in Fig. 6a-c separately for observations of biomass after years with exceptionally high versus lower mortality rates in the preceding year (Fig. $7 \mathrm{a}-\mathrm{c}$ ). These included (in Cerastoderma edule and Mytilus edulis) observations after a year with an instantaneous rate of mortality $z$ exceeding $2 \mathrm{yr}^{-1}$ or (in Macoma balthica) the years after 2000, when the proportions of adults were very low as a consequence of enhanced mortality rates for several preceding years. For Macoma balthica, the only species with a significant effect of preceding individualweight variability on biomass, we also show (Fig. 7b) data for years starting with above- and below-average individual weights at an age of $\sim 1.8 \mathrm{yr}$ (derived from data in Fig. 5b: above and below $0.014 \mathrm{~g}$ ), but only for the years before 2000, when the populations had a 'normal' age composition.

These itemized data sets still showed significant relationships (see $\mathrm{r}^{2}$ values included in Fig. 7) between observed and expected biomass values, as 

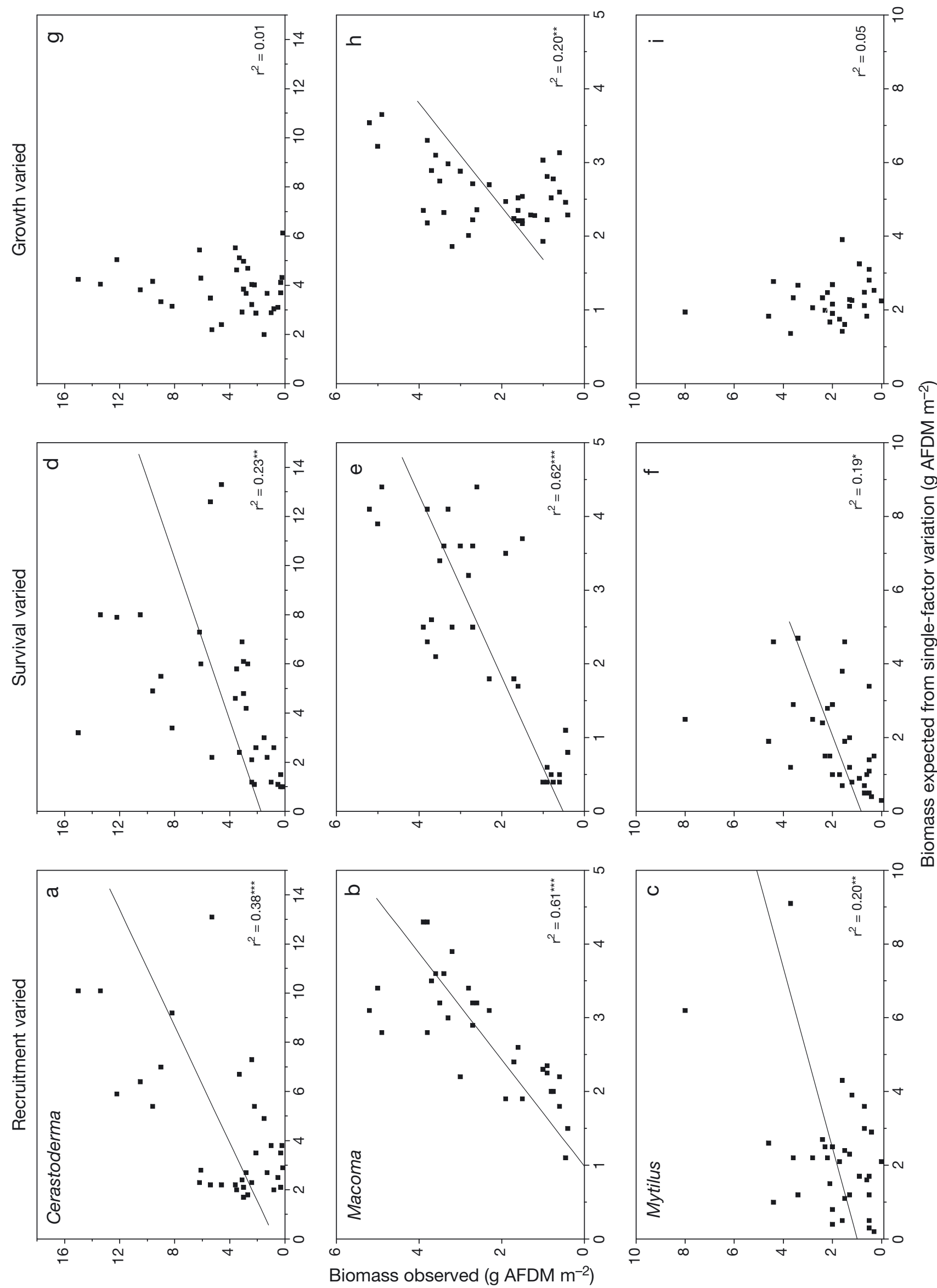
Fig. 6. $(\mathrm{a}, \mathrm{d}, \mathrm{g})$ Cerastoderma edule, (b,e,h) Macoma balthica and $(\mathrm{c}, \mathrm{f}, \mathrm{i})$ Mytilus edulis. Relationships between observed ( $y$-axis: $B_{\text {obs }}$ ) annual late-winter biomass values and estimates of values to be expected ( $x$-axis: $B_{\exp }$ ) when only 1 of 3 underlying factors varied during preceding years: $(\mathrm{a}, \mathrm{b}, \mathrm{c})$ annual recruitment; (d,e,f) annual survival; $(g, h, i)$ annual growth. All biomass values are expressed in $\mathrm{g} \mathrm{AFDM} \mathrm{m}^{-2}$ and refer to sums of contributions of several cohorts born in earlier years (as shown by $O$ on a per-recruit base in Fig. 1). Best fitting straight lines between expected and observed biomass values are shown in statistically significant relationships only, indicated for the accompanying value of $\mathrm{r}^{2}\left({ }^{*} \mathrm{p}<0.05,{ }^{* *} \mathrm{p}<0.01\right.$, and ${ }^{* * *} \mathrm{p}<0.001$, without correction for multiple comparisons). (a) $B_{\text {obs }}=0.64+0.85 B_{\exp }(\mathrm{n}=35)$, (b) $B_{\text {obs }}=-1.13+1.31$ $B_{\exp }(\mathrm{n}=33),(\mathrm{c}) B_{\mathrm{obs}}=1.01+0.47 B_{\exp }(\mathrm{n}=35),(\mathrm{d}) B_{\mathrm{obs}}=1.74+$ $0.61 B_{\exp }(\mathrm{n}=33)$, (e) $B_{\mathrm{obs}}=0.52+0.81 B_{\exp }(\mathrm{n}=31)$, (f) $B_{\mathrm{obs}}=$ $0.83+0.57 B_{\exp }(\mathrm{n}=32),(\mathrm{g}) B_{\mathrm{obs}}=2.91+0.35 B_{\exp }(\mathrm{n}=35)$, (h) $B_{\text {obs }}=-1.39+1.42 B_{\exp }(\mathrm{n}=38)$, (i) $B_{\text {obs }}=3.56-0.66 B_{\exp }$ $(n=30)$

shown above for the complete data sets. As anticipated, observed biomass was lower (at similar expected values) after years with high mortality
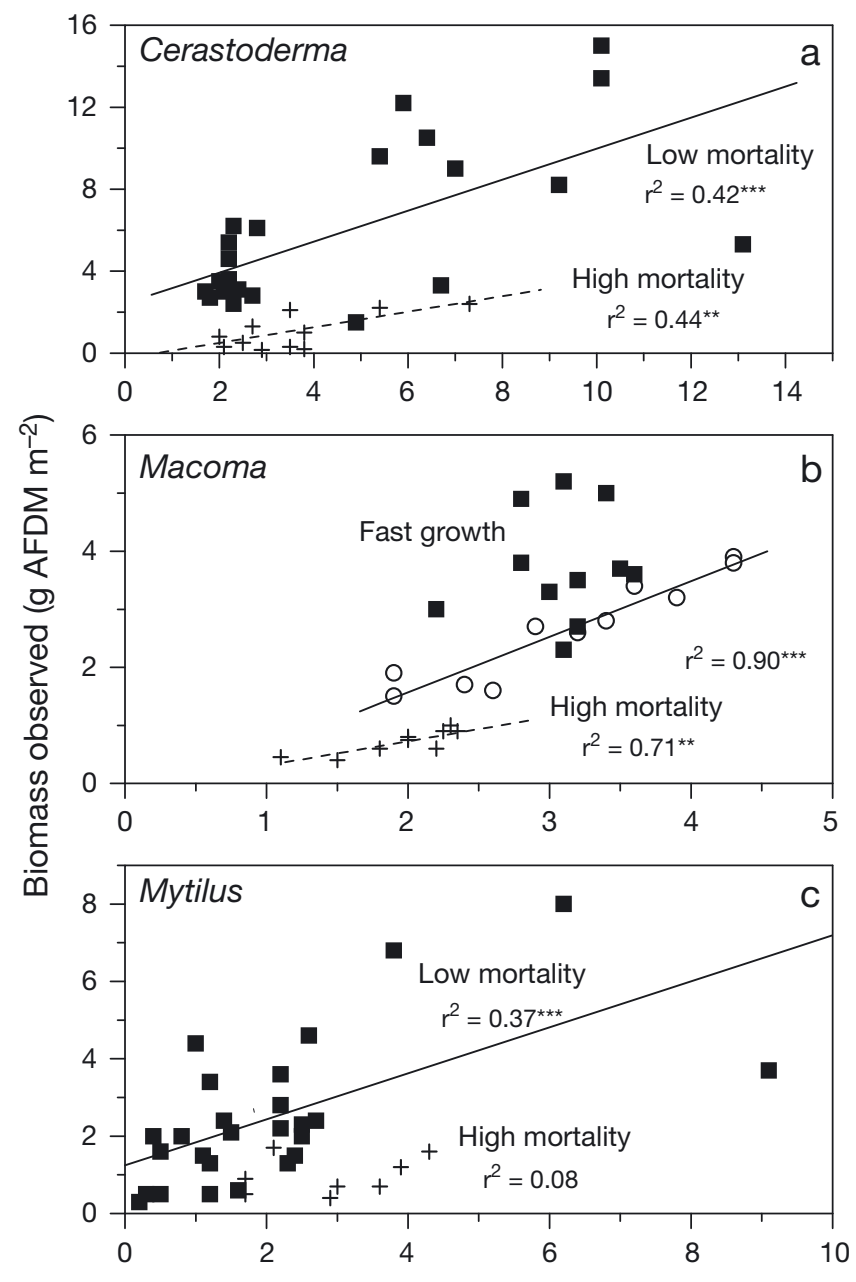

Biomass expected from recruitment ( $\mathrm{g}$ AFDM m ${ }^{-2}$ ) than after other years, and the differences were large ( 4-fold in all panels of Fig. 7). The influence of differences in growth (Fig. 7b) was much less $(<2$-fold).

Note that in Macoma balthica, the mortality variability-based values of expected biomass (Fig. 6e) were clustered, showing a separate group of 9 low values of mostly $<1 \mathrm{~g}$ AFDM m ${ }^{-2}$. These 9 values refer to the years after 2000, when large individuals of this species were scarce as a consequence of enhanced adult mortality rates (compare Fig. 4b). The correlation between mortality-variability expected and observed biomass for the earlier $22 \mathrm{yr}$ included in Fig. 6e was statistically non-significant $\left(\mathrm{r}^{2}=0.16, \mathrm{p}=0.06\right)$. For this initial $22 \mathrm{yr}$ period, the recruitment-variability expected values correlated significantly with observed values $\left(\mathrm{r}^{2}=0.26\right.$, $\mathrm{p}=0.015)$, as did the growth-variability expected values $\left(\mathrm{r}^{2}=0.49, \mathrm{n}=29, \mathrm{p}<0.0001\right)$. Thus, for the initial 22 yr period, recruitment and growth (but not mortality) were significant predictors of biomass variability, whereas for the entire period of observation (after inclusion of the last $9 \mathrm{yr}$, when mortality rates were much higher) mortality had to be added as a significant factor that was of similar importance as recruitment variability ( $\mathrm{r}^{2}$ values of 0.62 and 0.61 , respectively; see Fig. 6b,e).

\section{Total bird-accessible bivalve biomass}

To what extent do the above individual speciesbased relationships between single-factor expectations and actually observed biomass also predict total bivalve biomass accessible to shellfish-eating birds? Sums of expected biomass values of the 3 species studied did show a fair correlation with total accessible biomass (sums of these 3 species plus several minor species, see Fig. 2a) if the 3-species sums were based on either preceding recruitment (Fig. 8a) or on pre-

Fig. 7. (a) Cerastoderma edule, (b) Macoma balthica and (c) Mytilus edulis. Relationships between observed ( $y$-axis: $B_{\text {obs }}$ ) annual late-winter biomass values and estimates of values to be expected ( $x$-axis: $B_{\exp }$ ) at supposedly fixed rates of survival and growth, as in Fig. 6a,b,c, but now separately shown for observations after single years of reduced survival (+ and dashed lines). In (b) data for the low-mortality period is also given separately for above- and below-average mean individual weights ( $\boldsymbol{\square}$ and $O$ with solid line, respectively) for $M$. balthica. Best fitting straight lines between expected and observed biomass values are shown in statistically significant relationships, indicated for the accompanying value of $\mathrm{r}^{2}\left({ }^{*} \mathrm{p}\right.$ $<0.05,{ }^{* *} \mathrm{p}<0.01$, and ${ }^{* * *} \mathrm{p}<0.001$ ). (a) Low mortality: $B_{\text {obs }}=$ $2.4+0.76 B_{\exp }(\mathrm{n}=23)$ and high mortality: $B_{\mathrm{obs}}=-0.26+0.38$ $B_{\exp }(\mathrm{n}=12) ;(\mathrm{b})$ low mortality/slow growth: $B_{\mathrm{obs}}=-0.35+0.96$ $B_{\exp }(\mathrm{n}=11)$ and high mortality: $B_{\mathrm{obs}}=-0.12+0.43 B_{\exp }(\mathrm{n}=9)$; (c) low mortality: $B_{\text {obs }}=1.25+0.59 B_{\exp }(\mathrm{n}=26)$ 


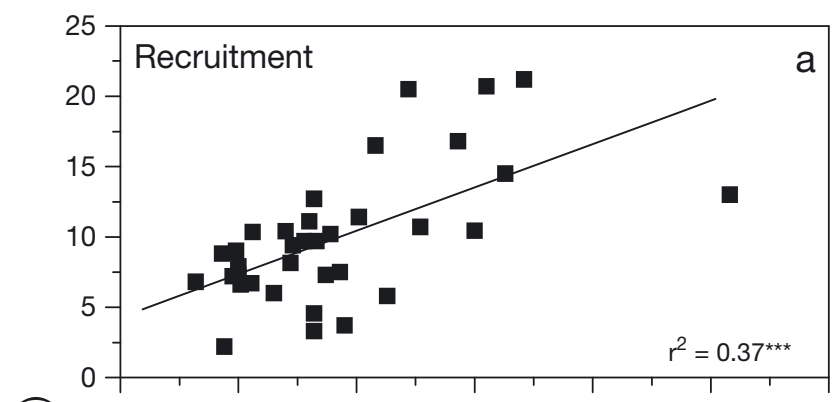

है

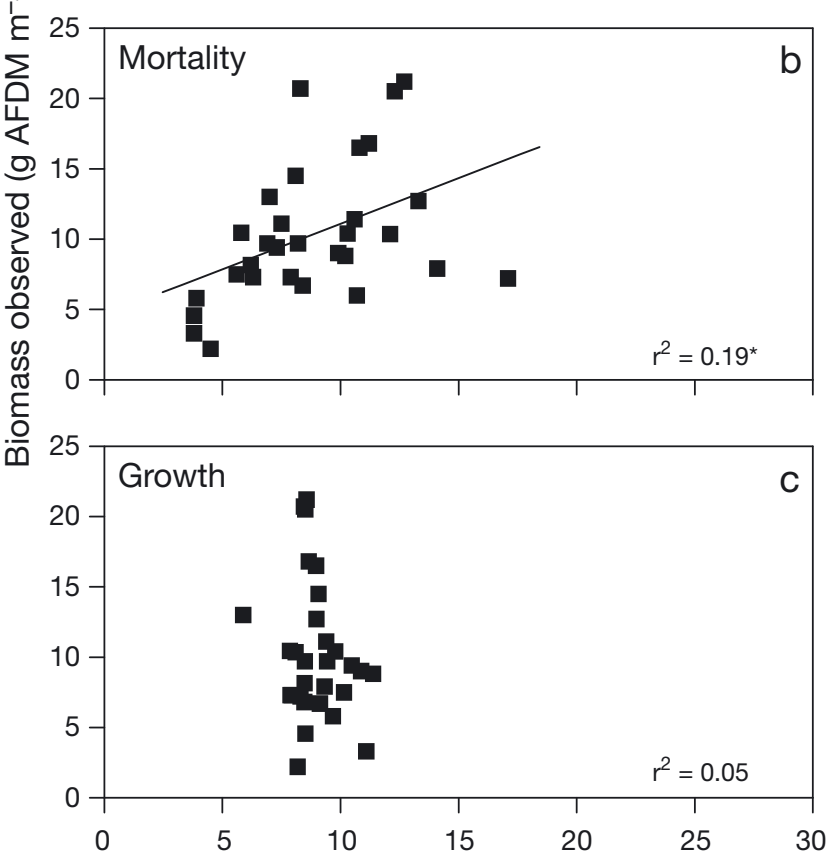

Biomass expected from single-factor variation (g AFDM m-2)

Fig. 8. Relationships between observed biomass (g AFDM $\mathrm{m}^{-2}$ ) in late winter of all bird-accessible bivalves ( $y$-axis: $B_{\text {obstotal }}$ shown in Fig. 2a) and summed (all 3 species) biomass expected (see Fig. $6 a, b, c)$ from variation in (a) recruitment (b) survival, and (c) growth in earlier years ( $X$-axis: $B_{\text {exp3sp }}$ ). The best fitting straight lines between expected and observed biomass values are shown only in statistically significant relationships, indicated by the accompanying value of $\mathrm{r}^{2}$ $\left({ }^{*} \mathrm{p}<0.05,{ }^{* *} \mathrm{p}<0.01\right.$, and $\left.{ }^{* * *} \mathrm{p}<0.001\right)$. (a) $B_{\text {obstotal }}=4.3+$ $0.62 B_{\text {exp3sp }}(\mathrm{n}=35)$, (b) $B_{\text {obstotal }}=4.6+0.65 B_{\text {exp3sp }}(\mathrm{n}=30)$, (c) $B_{\text {obstotal }}=18.9-0.96 B_{\exp 3 \mathrm{sp}}(\mathrm{n}=29)$

ceding mortality (Fig. 8b), but not on individual weights (Fig. 8c). Recruitment-based expectations of biomass were much closer to the actually observed values (Fig. 8a: a highly significant $\mathrm{r}^{2}$ value) than mortality-based estimates (Fig. 8b: a lower and hardly significant $\mathrm{r}^{2}$ ). Variation in individual weights (resulting mainly from growth variability in the preceding year) could not predict biomass (Fig. 8c: a low and nonsignificant $\mathrm{r}^{2}$ value).

\section{DISCUSSION}

At least 3 separate factors were shown to contribute to long-term biomass variability in Wadden Sea bivalves that could be important as bird food: preceding rates of recruitment, mortality, and growth (Fig. 6). For reasons explained in the 'Introduction', we did not include influences of migration on biomass in the present study.

Among the 3 above factors, growth rates appeared to be of lower importance than the other two. Growth showed relatively low between-year variability in all 3 species studied (Table 1, Fig. 5) and it was a statistically significant factor in only one of them. Moreover, even in this one species (Macoma balthica), growth rate variability contributed much less to biomass variability than either recruitment or mortality (Fig. 6). Thus, processes such as recruitment and mortality that govern numerical densities $\left(\mathrm{n} \mathrm{m}^{-2}\right)$ rather than those that affect individual weights (i.e. seasonal growth and weight loss, see Beukema et al. 2009) appear to be preponderant for biomass variability.

Mortality rates (shown in Fig. 4) showed intermediate between-year variability as compared to the relatively low variability in growth and high variability in recruitment (Table 1). A substantial influence of the exceptionally high mortality rates in some years on subsequent biomass could clearly be identified in all 3 species (Fig. 7: crosses versus other points). In Cerastoderma edule, biomass showed strongly reduced values after all severe winters (Fig. 2b) when their survival in the Wadden Sea is low (Beukema 1985, 1990, Strasser et al. 2001). Low biomass values can also occur after less extremely cold winters if the cockles happen to be restricted to high tidal flats (as in 2003) where they are more vulnerable to low temperatures than at the lower flats, where they usually show maximal abundance (Beukema \& Dekker 2009). In Mytilus edulis, high mortality rates were less restricted to cold winters, but there were several extremely high values in years including cold winters, when extensive parts of mussel beds sometimes disappeared as a result of ice-scouring. In these 2 species, high mortality was thus of an erratic character, i.e. it was mostly restricted to short periods of 1 or a few years, mostly in connection with coincidentally occurring severe winters. In Macoma balthica, on the other hand, a different pattern was found: a long period of rather constant and low annual mortality rates was rather suddenly followed by a period of enhanced mortality with unknown causes (Fig. 4b).

In all 3 species studied, recruitment was highly variable from year to year (Table 1, Fig. 3; Beukema \& Dekker 2005). Variability in preceding recruitment explained a significant part of the observed variability 
in biomass values, particularly after years with nonexceptional mortality rates (Fig. 7). As total biomass of a species in any year is usually composed of contributions of several cohorts, a study of the relationship between total species biomass and preceding processes should include several preceding years, not just the one before the biomass record. The way we quantitatively investigated such relationships was by summation of expected contributions of several individual cohorts on the basis of variation in 1 factor (recruit density, annual survival, or individual mean weight) while treating the other 2 factors as constants. The thereby obtained single-factor-based estimates for expected biomass proved to be fair predictors of actual biomass only when based on variability in number-governing processes: either recruitment or mortality/survival. As we defined recruitment as numerical densities of individuals of $\sim 0.8 \mathrm{yr}$ (though still of spat size), recruit densities were established after a long $(8 \mathrm{mo})$ period of exposure to (variable) mortality after their settlement. Recruitment variability thus inevitably includes some mortality variability.

Not only biomass of individual species, but also total bird-accessible bivalve biomass could be predicted to a large extent from preceding recruitment rates in the main species (Fig. 8a) and to a lesser extent from their preceding mortality rates (Fig. 8b). Recruitment success and failure are synchronized in several bivalve species in the Wadden Sea (Beukema et al. 2001): for a long period, strong cohorts arose more or less simultaneously once every $\sim 4$ yr. Recruitments were particularly successful after cold winters. In these years, shrimps Crangon crangon were scarce on tidal flats at the time of bivalve settlement (Beukema et al. 2001, Beukema \& Dekker 2005). Such synchronization will not only contribute to between-year variability in total (multi-species) recruit abundance and consequently in recruitment-expected biomass and total actually occurring biomass, but will also improve predictability of total bivalve biomass from assessments of preceding recruitment rates in only a few (key) species. However, during the last 1 or 2 decades, severe winters became infrequent, strong bivalve cohorts no longer arose, and the earlier synchronization with 4 yr intervals vanished.

The preponderant influence of recruitment on subsequent biomass in tidal-flat bivalves was expected from earlier studies on effects of recruitment variability on secondary production by cohorts of these species (Cerastoderma edule: Beukema \& Dekker 2006; Macoma balthica: Van der Meer et al. 2001, Dekker \& Beukema 2007; Mytilus edulis: Beukema \& Dekker 2007). In other habitats, however, recruitment may be less decisive for biomass, e.g. when a factor such as available suitable space limits adult abundance. For instance, Menge et al. (2009) report that a period with dramatically increased recruitment in mussels did not result in enhanced adult stocks in the rocky intertidal at several sites along the North American Pacific coast.

The relatively low values of bird-accessible bivalves found for the last dozen years on Balgzand (Fig. 2a) were due to low biomass in Cerastoderma edule (Fig. 2b) and Macoma balthica (Fig. 2c), and coincided with continuously low recruitment success in these species (Fig. 3a,b) and thus low values for expected biomass. Though recent biomass values in the third species, the blue mussel Mytilus edulis, were not extremely low on Balgzand (Fig. 2d), they have been very low over most of the other western Wadden Sea tidal-flat areas ever since the excessive fishing around 1990 (Steenbergen et al. 2005, Goudswaard et al. 2006, Beukema \& Dekker 2007). Failing recruitment, perhaps due to lack of sufficient hard substrates such as persistent mussel beds, is considered to be a main cause for low abundance of western Wadden Sea mussels (Ens et al. 2004). Recruitment failures thus appear to be a major cause of recently low biomass in all 3 species in the Wadden Sea. In M. balthica, but certainly not in C. edule, high mortality for a series of years (Fig. 4) has aggravated the situation during the last 1 or 2 decades, when low recruitment (Fig. 3b) coincided with high mortality (Fig. 4b) in the former species. In conclusion: failing recruitment appears to be the only common decisive factor for an explanation of the recently low stocks of food for bivalve-eating birds. Any explanation of the present low stocks of birdexploitable bivalves should, therefore, include a study of possible causes of the presently frequent occurrence of recruitment failures. Such failures in recent years were not restricted to the western part of the Wadden Sea (Beukema et al. 2001, Strasser et al. 2003). Examples of recent declines in bivalve abundance in various parts of the Wadden Sea can be found in Van der Graaf et al. (2009). Synchronization in bivalve biomass values over wide geographic areas is expected, as recruitment in several bivalve species (Beukema et al. 2001) as well as mortality in cockles (Beukema 1985) are related to winter temperatures, and winter character is similar over wide geographic areas (Beukema et al. 1996). We think that the findings on Balgzand may be generalized to the entire Wadden Sea.

Further studies of these bivalves should reveal to what extent environmental changes affect recruitment success and other processes (such as mortality and growth) underlying biomass change. Environmental changes to be included in such studies are (1) eutrophication and de-eutrophication (as expressed in e.g. changing concentrations of chlorophyll $a$ and particularly diatoms: Philippart et al. 2007), (2) climate change (rising temperatures for the last 2 decades in all sea- 
sons: Van Aken 2008), and (3) changes in sediment composition (declining mud contents: Zwarts 2003). De-eutrophication as a cause of recently low bivalve stocks has been suggested by Brinkman \& Smaal (2003) and Ens (2006), climate warming by Beukema (1992), Philippart et al. (2003), Beukema \& Dekker (2005), and Beukema et al. (2009), and fishery disturbance by Piersma et al. (2001), Van Gils et al. (2006), Piersma (2007), and Kraan et al. (2009).

The above conclusion should be regarded as valid only for the 4-decade study period. It is well imaginable that a drastic decline of primary production or substantial increase in abundance of other primary consumers than the studied species could shift the present emphasis on variability of numbers to a more important role of growth variation. The recent fate of the Macoma balthica population provides an example of a shift in emphasis: the identification of a predominant role of 2 processes (recruitment and growth) in determining biomass had to be changed only recently by recognition of the additional significant role of mortality. Some caution is thus warranted when conclusions are based on data series that are either short or show little between-year variability. Prolonged and consistent collection of both numerical and weight data are a prerequisite for obtaining some basic understanding of ecosystem dynamics.

So far, most studies are of a correlative nature, lacking a proper foundation of cause-effect studies of underlying processes. Therefore, we would plead for a study of underlying processes rather than of mere correlations. In this vision, only analytic causative studies of mechanisms could fully explain large-scale alterations in the Wadden Sea ecosystem, including the recent problems of food supply for shellfish-eating birds. As a first step, in the present study, we have identified changes in numerical abundance (by recruitment and also by subsequent mortality) as the main determinants of biomass variability, with only a minor role for changes in growth.

Acknowledgements. This study is part of a long-term monitoring program of macrozoobenthos in the Wadden Sea executed by NIOZ and financially supported by the Dutch Ministry of Transport, Public Works and Water Management, Water Service (RWS-Waterdienst). We thank J. van Gils, H. van der Veer and 3 anonymous reviewers for their comments on an earlier version of the paper.

\section{LITERATURE CITED}

Beukema JJ (1976) Biomass and species richness of the macrobenthic animals living on the tidal flats of the Dutch Wadden Sea. Neth J Sea Res 10:236-261

Beukema JJ (1985). Zoobenthos survival during severe winters on high and low tidal flats in the Dutch Wadden Sea.
In: Gray JS, Christiansen ME (eds) Marine biology of polar regions and effects of stress on marine organisms. John Wiley, Chichester, p 351-361

Beukema JJ (1990) Expected effects of changes in winter temperatures on benthic animals living in soft sediments in coastal North Sea areas. In: Beukema JJ, Wolff WJ, Brouns JJWM (eds) Expected effects of climatic change on marine coastal ecosystems. Kluwer Academic Publishers, Dordrecht, p 83-92

Beukema JJ (1991) Changes in composition of bottom fauna of a tidal-flat area during a period of eutrophication. Mar Biol 111:293-301

Beukema JJ (1992) Expected changes in the Wadden Sea benthos in a warmer world: lessons from periods with mild winters. Neth J Sea Res 30:73-79

$>$ Beukema JJ (1993a) Successive changes in distribution patterns as an adaptive strategy in the bivalve Macoma balthica (L.) in the Wadden Sea. Helgol Meersunters 47: $287-304$

$>$ Beukema JJ (1993b) Increased mortality in alternative bivalve prey during a period when the tidal flats of the Dutch Wadden Sea were devoid of mussels. Neth J Sea Res 31:395-406

Beukema JJ (1995) Long-term effects of mechanical harvesting of lugworms Arenicola marina on the zoobenthic community of a tidal flat in the Wadden Sea. Neth J Sea Res $33: 219-227$

Beukema JJ, Cadée GC (1991) Growth rates of the bivalve Macoma balthica in the Wadden Sea during a period of eutrophication: relationships with concentrations of pelagic diatoms and flagellates. Mar Ecol Prog Ser 68: 249-256

> Beukema JJ, Cadée GC (1997) Local differences in macrozoobenthic response to enhanced food supply caused by mild eutrophication in a Wadden Sea area: food is only locally a limiting factor. Limnol Oceanogr 42:1424-1435

Beukema JJ, Dekker R (2005) Decline of recruitment success in cockles and other bivalves in the Wadden Sea: possible role of climate change, predation on postlarvae and fisheries. Mar Ecol Prog Ser 287:149-167

- Beukema JJ, Dekker R (2006) Annual cockle Cerastoderma edule production in the Wadden Sea usually fails to sustain both wintering birds and a commercial fishery. Mar Ecol Prog Ser 309:189-204

Beukema JJ, Dekker R (2007) Variability in annual recruitment success as a determinant of long-term and largescale variation in annual production of intertidal Wadden Sea mussels (Mytilus edulis). Helgol Mar Res 61:71-86

> Beukema JJ, Dekker R (2009) The intertidal zoning of cockles (Cerastoderma edule) in the Wadden Sea, or why cockle fishery disturbed areas of relatively high biodiversity. Helgol Mar Res 63:287-291

Beukema JJ, Cadée GC, Hummel H (1983) Differential variability in time and space of numbers in suspension and deposit feeding benthic species in a tidal flat area. Oceanol Acta No Sp.: 21-26

> Beukema JJ, Essink K, Michaelis H, Zwarts L (1993) Year-toyear variability in the biomass of macrobenthic animals on tidal flats of the Wadden Sea: how predictable is this food source for birds? Neth J Sea Res 31:319-330

- Beukema JJ, Essink K, Michaelis H (1996) The geographic scale of synchronized fluctuation patterns in zoobenthos populations as a key to underlying factors: climatic or man-induced. ICES J Mar Sci 53:964-971

> Beukema JJ, Flach EC, Dekker R, Starink M (1999) A longterm study of the recovery of the macrozoobenthos on large defaunated plots on a tidal flat in the Wadden Sea. J Sea Res 42:235-254 
Beukema JJ, Dekker R, Essink K, Michaelis H (2001) Synchronized reproductive success of the main bivalve species in the Wadden Sea: causes and consequences. Mar Ecol Prog Ser 211:143-155

Beukema JJ, Cadée GC, Dekker R (2002) Zoobenthic biomass limited by phytoplankton abundance: evidence from parallel changes in two long-term data series in the Wadden Sea. J Sea Res 48:111-125

Beukema JJ, Dekker R, Jansen JM (2009) Some like it cold: populations of the tellinid bivalve Macoma balthica (L.) suffer in various ways from a warming climate. Mar Ecol Prog Ser 384:135-145

Brinkman AG, Smaal AC (2003) Onttrekking en natuurlijke produktie van schelpdieren in de Nederlandse Waddenzee in de periode 1976-1999. Alterra-rapport 888, Alterra, Wageningen

Camphuysen CJ, Ens BJ, Heg D, Hulscher JB, Van der Meer J, Smit CJ (1996) Oystercatcher Haematopus ostralegus winter mortality in the Netherlands: the effect of severe weather and food supply. Ardea 84A:469-492

Camphuysen CJ, Berrevoets CM, Cremers HJWM, Dekinga A and others (2002) Mass mortality of common eiders (Somateria mollissima) in the Dutch Wadden Sea, winter 1999/2000: starvation in a commercially exploited wetland of international importance. Biol Conserv 106:303-317

Dekker R (2009) Het macrozoobenthos op twaalf raaien in de Waddenzee en de Eems-Dollard in 2008. NIOZ-Rapport, NIOZ, Texel, October 2009

Dekker R, Beukema JJ (2007) Long-term and large-scale variability in productivity of the tellinid bivalve Macoma balthica on Wadden Sea tidal flats. Mar Ecol Prog Ser 337:117-134

Dörjes J, Michaelis H, Rhode B (1986) Long-term studies of macrozoobenthos in intertidal and shallow subtidal habitats near the island of Norderney (East Frisian coast, Germany). Hydrobiologia 142:217-232

Ens BJ (2006) The conflict between shellfisheries and migratory waterbirds in the Dutch Wadden Sea. In: Boere GC, Galbraith CA, Stroud DA (eds) Waterbirds around the world. The Stationery Office, Edinburgh, p 806-811

Ens BJ, Smaal AC, De Vlas J (2004) The effects of shellfish fishery on the ecosystem of the Dutch Wadden Sea and Oosterschelde. Alterra-rapport 1011, Alterra, Wageningen

Ens BJ, Kats R, Camphuysen CJ (2006) Waarom zijn Eiders niet massaal gestorven in de winter van 2005/2006? Limosa 79:95-106

Essink K, Beukema JJ, Madsen PB, Michaelis H, Vedel GR (1998) Long-term development of biomass of intertidal macrozoobenthos in different parts of the Wadden Sea. Governed by nutrient loads? Senckenb Marit 29:25-35

Goudswaard PC, Steenbergen J, Baars JMDD, Kesteloo JJ, Jol J, Van Stralen MR (2006) Het mosselbestand en het areaal aan mosselbanken op de droogvallende platen in de Waddenzee in het voorjaar van 2006. IMARES Rapport C059/06, Wageningen

Kats R (2007) Common eiders Somateria mollissima in the Netherlands. The rise and fall of breeding and wintering populations in relation to the stocks of shellfish. PhD thesis, University of Groningen. Alterra Sci Contr 19: $1-336$

Kraan C, Van Gils JA, Spaans B, Dekinga A and others (2009) Landscape-scale experiment demonstrates that Wadden Sea intertidal flats are used to capacity by molluscivore migrant shorebirds. J Anim Ecol 78:1259-1268

> Menge BA, Chan F, Nielsen KJ, Di Lorenzo E, Lubchenco J (2009) Climate variation alters supply-side ecology: impact of climate patterns on phytoplankton and mussel recruitment. Ecol Monogr 79:379-395

Möller P (1986) Physical factors and biological interactions regulating infauna in shallow boreal areas. Mar Ecol Prog Ser 30:33-47

Obert B, Michaelis H (1991) History and ecology of the mussel beds (Mytilus edulis L.) in the catchment area of a Wadden Sea tidal inlet. In: Elliott M, Ducrotoy J-P (eds) Estuaries and coasts. ECSA 19 Symposium. Olsen \& Olsen, Fredensborg, p 185-194

Philippart CJM, Van Aken HM, Beukema JJ, Bos OG, Cadée GC, Dekker R (2003) Climate-related changes in recruitment of the bivalve Macoma balthica. Limnol Oceanogr 48:2171-2185

Philippart CJM, Beukema JJ, Cadee GC, Dekker R and others (2007) Impacts of nutrient reduction on coastal communities. Ecosystems 10:96-116

Piersma T (2007) Why do molluscivorous shorebirds have such a hard time in the Wadden Sea right now? In: Reineking $B$, Südbeck $P$ (eds) Seriously declining trends in migratory waterbirds. Wadden Sea Ecosystem 23, Common Wadden Sea Secretariat, Wilhelmshaven, p 53-63

> Piersma T, Koolhaas A, Dekinga A, Beukema JJ, Dekker R, Essink K (2001) Long-term indirect effects of mechanical cockle-dredging on intertidal bivalve stocks in the Wadden Sea. J Appl Ecol 38:976-990

Scheiffarth G, Nehls G (1997) Consumption of benthic fauna by carnivorous birds in the Wadden Sea. Helgol Meersunters 51:373-387

Smit CJ (1983). Production of biomass by invertebrates and consumption by birds in the Dutch Wadden Sea area. In: Wolff WJ (ed) Ecology of the Wadden Sea. Balkema, Rotterdam, 2 (6):290-301

Steenbergen J, Baars JMDD, Kesteloo JJ, Jol J, Van Stralen MR, Craeymeersch JA (2005) Het mosselbestand en het areaal aan mosselbanken op de droogvallende platen in de Waddenzee in het voorjaar van 2005. RIVO Rapport C065/05, RIVO, IJmuiden

Strasser M, Reinwald T, Reise K (2001) Differential effects of the severe winter of $1995 / 96$ on the intertidal bivalves Mytilus edulis, Cerastoderma edule and Mya arenaria in the northern Wadden Sea. Helgol Mar Res 55:190-197

Strasser M, Dekker R, Essink K, Günther CP and others (2003) How predictable is high bivalve recruitment in the Wadden Sea after a severe winter? J Sea Res 49:47-57

Swennen C (1976) Wadden Seas are rare, hospitable and productive. In: Smart M (ed) Proc Int Conf Conserv Wetl Waterfowl. Int Waterfowl Res Bur, Slimbridge, p 184-198

Van Aken HM (2008) Variability of the water temperature in the western Wadden Sea on tidal to centennial scales. J Sea Res 60:227-234

Van der Graaf S, De Vlas J, Herlyn M, Voss J, Heyer K, Drent J (2009) Macrozoobenthos. Thematic report No 10. In: Marencic, H, De Vlas J (eds) Quality status report 2009. Common Wadden Sea Secretariat, Wilhelmshaven, p 1-27

Van der Meer J, Beukema JJ, Dekker R (2001) Long-term variability in secondary production of an intertidal bivalve population is primarily a matter of recruitment variability. J Anim Ecol 70:159-169

Van Gils JA, Piersma T, Dekinga A, Spaans B, Kraan C (2006) Shellfish dredging pushes a flexible avian top predator out of a marine protected area. PLoS Biol 4:e376

Van Roomen M, Van Turnhout C, Van Winden E, Koks B, Goedhart PW, Leopold MF, Smit CJ (2005) Trends van benthivore watervogels in de Nederlandse Waddenzee 
1975-2002: grote verschillen tussen schelpdiereters en wormeneters. Limosa 78:21-38

Zwarts L (2003) Bodemgesteldheid en mechanische kokkelvisserij in de Waddenzee. Rapport RIZA/2004.028, RIZA, Lelystad

Editorial responsibility: Hans Heinrich Janssen, Oldendorf/Luhe, Germany
Zwarts L, Wanink JH, Ens BJ (1996) Predicting seasonal and annual fluctuations in the local exploitation of different prey by oystercatchers Haematopus ostralegus: a ten-year study in the Wadden Sea. Ardea 84A: 401-440

Submitted: March 18, 2010; Accepted: June 17, 2010

Proofs received from author(s): August 24, 2010 